\title{
Human leukocyte antigens (HLA)
}

National Diabetes Information Clearinghouse (NDIC)

\section{Definitions}

Protein

Defined by National Diabetes Information Clearinghouse (NDIC)

Immune system

Defined by National Diabetes Information Clearinghouse (NDIC)

Type 1 diabetes

Defined by National Diabetes Information Clearinghouse (NDIC)

\section{Source}

National Diabetes Information Clearinghouse (U.S.). (2009). The diabetes dictionary. [Bethesda, Md.]: U.S. Dept. of Health and Human Services, National Institutes of Health, National Institute of Diabetes and Digestive and Kidney Diseases, National Diabetes Information Clearinghouse.

Proteins located on the surface of the cell that help the immune system identify the cell either as one belonging to the body or as one from outside the body. Some patterns of these proteins may mean increased risk of developing type 1 diabetes. 